\title{
Twarze dzieciństwa w twórczości Pawła Beręsewicza
}

Faces of childhood in the works by Paweł Beręsewicz

Abstract: The article is devoted to the analysis of Paweł Beręsewicz's works submitted, awarded with a prize or distinction at the Kornel Makuszyński All-Poland National Literary Award. The following books by Beręsewicz were analyzed: Jak zakochatem Kaśkę Kwiatek (2005), Ciumkowe historie, w tym jedna smutna (2007), Tajemnica człowieka z blizna (2010), Ściśle tajne (2018). The reading method draws upon the childhood face topic, which was suggested by Grzegorz Leszczyński.

Keywords: childhood, love, death, Paweł Beręsewicz, Kornel Makuszyński

Paweł Beręsewicz jest, jak do tej pory, jedynym autorem dwukrotnie nagrodzonym statuetką Koziołka Matołka w Ogólnopolskiej Nagrodzie Literackiej im. Kornela Makuszyńskiego. Nagroda została ustanowiona w 1994 roku i nieprzerwanie od lat wskazuje najlepsze polskie książki dla dzieci, które w wymowie nawiązują do słonecznej wizji twórczości patrona - Kornela Makuszyńskiego. W przypadku Beręsewicza są to: Jak zakochałem Kaśkę Kwiatek (Beręsewicz, 2005), Ciumkowe historie, w tym jedna smutna (Beręsewicz, 2007), Tajemnica człowieka z blizna (Beręsewicz, 2010), Ściśle tajne (Beręsewicz, 2018).

Założeniem niniejszego tekstu jest analiza tych utworów Pawła Beręsewicza, które zostały zgłoszone, nagrodzone lub wyróżnione w ramach konkursu. Za podstawę analizy przyjęłam Grzegorza Leszczyńskiego koncepcję twarzy dzieciństwa. To jedna $\mathrm{z}$ wielu możliwych metodologii, jakie proponują nauki o dziecku i dzieciństwie. Analizę skupię jedynie na literackich przedstawieniach dzieci w wybranych utworach Pawła Beręsewicza. W tekście tym nie skoncentruję się na odniesieniach do kontekstów historycznych, antropologicznych, socjologicznych, psychologicznych, pedagogicznych czy filozoficznych ${ }^{1}$. Przedstawię je-

${ }^{1}$ Zob. hasło Ewolucja poglądów na dziecko i okres dzieciństwa, w: Encyklopedia dzieciństwa. http://encyklopediadziecinstwa.pl/index.php/Ewolucja_pogl\%C4\%85d\%C3\%B3w_na_dziec 
dynie w zarysie ewolucję poglądów dotyczących badań nad dzieckiem i dzieciństwem.

Jak pisze Philippe Ariès we wstępie do drugiego wydania Historii dzieciństwa..., stosunek dorosłych do dzieci przez długi czas był obojętny. Zakłada się, że do XII wieku sztuka średniowiecza ignorowała dzieciństwo (Ariès, 1995, s. 43). W kolejnym wieku wykształciły trzy typy przedstawiania dzieci:

- w postaci anioła - młodziutkiego mężczyzny (Ariès, 1995, s. 44),

— Dzieciątka Jezus (Ariès, 1995, s. 45),

- dziecka nagiego - głównie w czasach gotyku (Ariès, 1995, s. 45).

Natomiast od przełomu XV i XVI wieku dzieci, głównie w malarstwie, przedstawiane są wraz z dorosłymi, stanowią integralną część ich świata (Ariès, 1995, s. 47). Proces dostrzegania odrębności dzieci rozpoczyna się dopiero w wieku XIX. Przybiera on na sile w takim stopniu, że kolejne stulecie Ellen Key, szwedzka pisarka, nauczycielka, pedagog oraz działaczka społeczna, nazywa stuleciem dziecka (Key, 2005). To właśnie ono stało się obszarem badawczym Grzegorza Leszczyńskiego, który w publikacji Kulturowy obraz dziecka i dzieciństwa w literaturze drugiej połowy XIX i w XX $w$.... wymienia sześć twarzy dzieciństwa, rozumianych jako paidalne toposy. Są to kolejno: zabawa, dom, szkoła, artystyczna dusza, człowiek czytający oraz spotkanie ze śmiercią. Posłużą jako podstawa do analizy literackich reprezentacji dzieci oraz ich przestrzeni w wybranych tekstach Pawła Beręsewicza.

\section{Homo ludens - ZABAWA}

Jak pisze Grzegorz Leszczyński, „nasze myślenie jest ufundowane przez zabawę, jest $\mathrm{z}$ samej swej istoty zabawowe (choć nie ludyczne), podobnie jak w społecznościach pierwotnych, które zabawę pojmują jako obustronną i uzależnioną od reguł próbę losu" (Leszczyński, 2006, s. 157).

Punkt wyjścia książki Tajemnica człowieka $z$ blizna stanowi gra w piłkę. Koledzy, którzy podczas wakacji spotykają się na boisku, aby „grać”, tak naprawdę rozmawiają. Nie są to rozmowy błahe; ich treść ma dla chłopców znaczenie niezwykle ważne, toteż podchodzą do spotkań bardzo poważnie. Rozmawiają o szkole (w której spędzają większość swojego życia i siłą rzeczy musi ona stanowić temat ich rozmów), o pierwszych fascynacjach dziewczynami ${ }^{2}$, historiach rodzinnych, czego przykładem jest opowieść o ojcu — powstańcu warszawskim.

ko_i_okres_dzieci\%C5\%84stwa [data dostępu: 24.03.2020]. Por. Jarosz, 2017, s. 58-59; Dymara, Ogrodzka-Mazur, 2013.

2 „Dziewczyny z kolei to temat wstydliwy, ale kuszący. Nie można też wykluczyć, że wstydliwy, więc kuszący. [...] Następowała cisza i moment niepewności, czy ktoś zaraz nie parsknie śmiechem, ale nie - nikt nie zamierzał się śmiać. To był znak, że ta kwestia wszystkim leżała na sercu i wyznania robiły się coraz śmielsze" (Beręsewicz, 2010, s. 6-7). 
Kolejnym przykładem swoistej gry jest zabawa w „zakochiwanie” Kaśki Kwiatek. Jacek Karaś próbuje wymyślić i zaaranżować sytuacje, w których rzeczona Kaśka się w nim zakocha. Choć czytelnikom wydaje się to śmieszne, Jacek podchodzi do zadania niezwykle poważnie. Dziadek z książki Ściśle tajne wciąga wnuczka w zabawę, aby ten zwrócił uwagę na to, czy na grobie będzie leżał listek, czy też nie, co ma być tajemniczym znakiem od nieżyjącej już babci. Ponadto dziadek zaprasza wnuczka do zabawy, mówiąc, że będzie to przygoda "Jak w Kapitanie Klossie" (Beręsewicz, 2018, s. 11), czyli odwołuje się postaci szpiega/ agenta z kręgu kultury popularnej.

Przedstawione „próby losu” odbywają się więc w zabawowej, lekkiej atmosferze, choć odnoszą się do tak ważnych kwestii, jak kontakt ze zmarłymi oraz tajemnica życia i śmierci (Ściśle tajne), pierwsza miłość (Jak zakochałem Kaśkę Kwiatek), rodzina oraz jej historia (Tajemnica człowieka z blizna).

\section{Homo domesticus - DOM}

Dom to druga $\mathrm{z}$ proponowanych przez Leszczyńskiego twarzy dzieciństwa. Opisuje się go jako podstawę egzystencji (Leszczyński, 2006, s. 159), a zarazem jeden z fundamentów kształtujących ludzki byt (Leszczyński, 2006, s. 194). Dom to nie tylko ściany, ale przede wszystkim rodzina i domownicy, czyli relacje łączące jej członków. W takim ujęciu dom stanowi centrum rodziny Ciumków, a jednym z przykładów niech będzie rozpoczynający opowieść opis strychu, na którym kryje się historia rodziny reprezentowana przez zgromadzone przedmioty:

Po otwarciu klapy w suficie wchodziło się po drabinie na strych. W lecie panował tam straszny upał, w zimie przejmujący chłód, a o każdej porze roku egipskie ciemności. Światło wpadające przez klapę rozpraszało nieco gęsty mrok, dzięki czemu wśród plątaniny drewnianych krokwi i słupów można było zobaczyć eksponaty Muzeum Historii Ciumków.

Beresęwicz, 2007, s. 5

Strych wypełniały stare pudła, sprzęt turystyczny, białe (ślubne) szpilki mamy, plastikowa wanienka, dziecięcy fotelik do karmienia, rozchybotany wózek, stare łóżeczko, rowerek... czyli zgodnie z nazwą był to zapis historii tej rodziny.

Codzienność Ciumków, ale też rodziny z Tajemnicy człowieka $z$ blizna to zwykłe sytuacje, które prawdopodobnie każdy z czytelników zna $\mathrm{z}$ własnego doświadczenia: rodzinne spotkania (Beręsewicz, 2010, s. 54), obiady u babci (Beręsewicz, 2007, s. 10), wspólne wyjazdy na grzyby (Beręsewicz, 2007, s. 11), wycieczki w góry (Beręsewicz, 2007, s. 70—77), spleśniała kanapka zapomniana 
w szkolnym plecaku czy sprzeczki z rodzeństwem (Beręsewicz, 2007, s. 45). Ważna w omawianych tu książkach jest historia rodziny, na przykład to, jak poznali się rodzice ${ }^{3}$. Dla Jaśka z Tajemnicy... niezwykle istotne znaczenie ma więź łącząca go z rodzicami. Syn nie możne pozostać obojętny wobec skrywanej przez ojca tajemnicy, a potem wobec sekretu matki.

Siła relacji przejawia się we wsparciu, jakie okazują sobie członkowie rodzin, a podkreślić należy, że w omawianych książkach Beręsewicza rodzinne więzi są bezwarunkowe. Przykładem jest tu historia Kasi z rodziny Ciumków, która szukając swej pasji, po kolei odrzuca zajęcia plastyczne (dlatego, że są głupie), tenis (kretyński), szachy (beznadziejne), szkolny chór (idiotyczny), by w końcu spróbować sił w balecie. Jak czytamy: „Na szczęście miała kochającą rodzinę i mogła zawsze liczyć na wsparcie ze strony każdego jej członków” (Beręsewicz, 2007, s. 30), wsparcie na tyle duże, że brak różowej, tiulowej sukieneczki podczas występu córki nie przeszkodził jej ojcu czuć prawdziwego wzruszenia (Beręsewicz, 2007, s. 35).

Równie silne więzi międzypokoleniowe opisane są w książce Ściśle tajne. Relacja łącząca wnuczka z Małym Dziadkiem pokonuje granicę dzielącą życie i śmierć. Dziadek komunikuje się z wnukiem nawet po swej śmierci. Z kolei inna więź wkracza dopiero w procesie tworzenia: to relacja bohatera opowiadania z nienarodzonym jeszcze rodzeństwem.

\section{Homo scholasticus - SZKOŁA}

Szkoła jest dziś „naturalną” przestrzenią dzieci, więc to oczywiste, że tematy $\mathrm{z}$ nią związane znajdujemy w książkach opisujących ich historie. To w szkole mają miejsce „miłosne przygody” Jacka i Kaśki, to szkolni koledzy są świadkami czy inicjatorami różnych działań, na przykład rozmów o piłce nożnej w czasie szkolnej przerwy, podrzucenia dżdżownic do zeszytu koleżanki, podszywania się pod kolegów podczas dzwonienia domofonem. To kolegom ze szkoły Jasiek opowiada historie z Powstania Warszawskiego, chwaląc się uczestnictwem swego ojca w powstańczych walkach: „Tak naprawdę, kiedy mój stary był w powstaniu, wcale nie był jeszcze stary. Przeciwnie, był całkiem młody — tak młody, że młodszym być nie można. Mój stary się po prostu w czasie powstania urodził" (Beręsewicz, 2010, s. 9).

Koledzy z klasy tworzyli audytorium bohatera Ściśle tajnego, gdy ten z dumą opowiadał o pobycie w Paryżu:

${ }^{3} \mathrm{~W}$ przypadku Ciumków są to wspomnienia o „ukradzionym” żurku z perspektywy mamy i taty, a w Tajemnicy człowieka z blizna fabuła zmierza do finałowego odkrycia dotyczącego okoliczności powstania blizny na twarzy taty. Ujawnienie jej jest tyleż zaskakujące, co romantyczne. Okazuje się, że blizna jest efektem szalonej wspinaczki do okna na drugim piętrze budynku, w którym mieszkała ukochana ojca, jego przyszła żona (Beręsewicz, 2010, s. 171-176, 180-182). 
Powiedziałem chłopakom, że byłem z rodzicami w Paryżu. Wszyscy inni gdzieś byli i nie chciałem wyjść na takiego, co to nosa nie wytknął poza własne podwórko. Poza tym ja naprawdę byłem w Paryżu. [...] A chłopaki na to, że w brzuchu się nie liczy; nie liczy. Że nie byłem w Paryżu, skoro mnie wtedy jeszcze w ogóle nie było.

Beręsewicz, 2018, s. 27-30

Świat szkoły postaci powołanych przez Beręsewicza to przestrzeń ludzi młodych, rządząca się ich prawami. Dorośli, jeśli się w niej pojawiają, są groteskowi i nie przystają do rytmu nastolatków. W nieprzystawalności celują nauczyciele, szczególnie Pani Pulwerska, nauczycielka języka polskiego, która uwielbia opowieści o miłości:

Miłość. To była miłość. Uff! Najgorsze mam już za sobą. Myślałem, że będzie trudniej. Jednak o rzeczach wstydliwych łatwiej jest pisać, niż mówić. To słowo zawsze z trudem przechodziło mi przez gardło i wymawiałem je na głos tylko wtedy, kiedy byłem do tego naprawdę zmuszony. A najczęściej zmuszała mnie pani Pulwerska, nasza wychowawczyni i polonistka, która ze wszystkich słów na świecie to lubiła chyba najbardziej.

- Stracili cały dobytek - mówiła na przykład w czasie omawiania jakiejś lektury - ale mieli siebie, więc byli bardzo, bardzo szczęśliwi, bo najważniejszą rzeczą na świecie jest...? [...] - No to może... Jacek Karaś nam powie - mówiła w końcu i słodko uśmiechnięta stawała przy mojej ławce. - Najważniejszą rzeczą na świecie, Jacku, jest...? [...]

- Młść - mówiłem, jakbym wypluwał jakieś paskudztwo [...].

Beręsewicz, 2005, s. 5-7

Szkoła wraz z nauczycielami jest zatem jedynie tłem rozgrywających się wydarzeń, a siłę sprawczą mają szkolni koledzy.

\section{Homo artefix — człowiek artysta — ARTYSTYCZNA DUSZA}

Jeśli zawęzilibyśmy rozumienie pojęcia „artysta” jedynie do „człowieka wrażliwego" na świat, jego barwy, odgłosy i nastroje (Leszczyński, 2006, s. 226), to wszyscy bohaterowie omawianych utworów są artystami. Żywo i energicznie reagują na świat, sami również ten świat kreując. Noszą oni jednak w sobie raczej nie pierwiastek artysty, lecz trikstera ${ }^{4}$. Choć nie kłamią i nie są łotrzyka-

4 Trickster $\mathrm{w}$ religioznawstwie to bóg lub półbóg przeciwstawiający się ustalonym normom przez żarty, oszukiwanie, kradzież. Internetowy słownik języka polskiego. https://sjp.pl/trickster [data dostępu: 22.08.2019]. Zobacz też hasło „trikster” w Encyklopedii Fantastyki. http://encyklopediafantastyki.pl/index.php/Trickster [data dostępu: 22.08.2019]. Szerzej postać trickstera opisuje Leszczyński w artykule Trickster artysta. Ponowoczesne gry archetypowe (Leszczyński, 2012, s. 137-164) oraz Michał Zając (Zając, 2013, s. 121-154). 
mi, którzy burzą porządek świata, to starają się go kreować na swoją modłę. Na plan pierwszy wysuwa się postać Jacka, bohatera książki Jak zakochałem Kaśkę Kwiatek, dążącego do wzbudzenia gorącego uczucia w koleżance z klasy. Robi to w przezabawny sposób, ponieważ najpierw buduje scenariusze działania, a następnie przy nadarzającej się sposobności stara się je zrealizować. Plany Jacka oscylowały wokół bohaterskiego uratowania Kaśki z płonącego bloku, wspólnego pisania referatu o polskich noblistach czy romantycznego powrotu ze szkolnej wycieczki. Nietrudno się domyślić, że ambitne plany chłopca nigdy nie dojdą do skutku: na szczęście nie dochodzi do wybuchu pożaru, temat referatu, nad którym pracują Kaśka oraz Jacek, dotyczy damskiego ubioru, a na domiar złego $\mathrm{w}$ tej intelektualnej przygodzie towarzyszy im kolega przydzielony przez nauczyciela do wykonania zadania, natomiast powracającego z wycieczki Jacka musi zadowolić obecność przysypiającego Bartka, który zajmuje miejsce Kaśki.

\section{Homo legens - człowiek czytający}

Najwyrazistszym przykładem „człowieka czytającego” jest bohater książki Ściśle tajne oraz jego misja „Pięć Niedźwiedzi”. Chłopiec wierzy w moc czytanego słowa. Chce, aby jego nienarodzony jeszcze brat pamiętał wszystko, nawet to, co działo się przed jego pojawieniem się na świecie. Bohater przez pięć miesięcy czyta więc swemu bratu opowieści o niedźwiedziach. Starszy brat dzięki głośnej lekturze wpisuje nienarodzonego jeszcze członka rodziny w opowieść, której częścią za chwilę się stanie.

\section{Spotkanie ze śmiercią}

Zagadnienie to, a w nomenklaturze Leszczyńskiego „szósta twarz”, przedstawione zostanie w odniesieniu do jednego tekstu, książki Ściśle tajne. Choć według Leszczyńskiego, „Kiedy pozna się śmierć, przestaje się być dzieckiem” (Leszczyński, 2006, s. 273), to wydaje się, że śmierć w książce Ściśle tajne pozostaje procesem naturalnym, mimo że utrata bliskich stanowi jedną $\mathrm{z}$ ważniejszych cezur dzieciństwa. Beręsewicz unika opisu procesu odchodzenia, rezygnuje z rozpaczliwych sygnałów poczucia straty i następującej po niej pustki po zmarłym dziadku. Jest za to radosna pamięć o bliskiej osobie, uruchamiana w sytuacjach i trudnych, i pięknych. Cudowne koło życia unaoczni się przed bohaterem w symbolicznej chwili: momencie narodzin jego braci bliźniaków. Wraz z pojawieniem się rodzeństwa chłopiec ma ważną misję do wykonania, musi przekazać braciom opowieść o zmarłym dziadku, a tym samym zachować ciągłość rodzinnej narracji. 


\section{Podsumowanie}

Chciałabym wskazać pewne „braki” fabularne omawianych książek, które choć łatwe do wychwycenia, nie deprecjonują wartości tych tytułów. Współczesnych czytelników może razić brak nowoczesnych technologii (takich jak komunikowanie się za pomocą internetowych aplikacji, powszechne korzystanie z telefonów komórkowych). Czy jest to jednak rzeczywiście pewne niedociągnięcie? Być może właśnie w taki sposób Beręsewicz realizuje formułę znaną z twórczości Makuszyńskiego, formułę, która stała się przesłaniem nagrody firmowanej nazwiskiem autora Panny z mokra głowa, zwanym „słonecznym pisarzem”. Formuła oznaczałaby więc nie tylko ukazywanie jasnych stron życia i pełnych humoru historii, ale przede wszystkim relacji międzyludzkich, opartych na autentycznym kontakcie, niezapośredniczonym przez nowe technologie. Fundamentem tych związków są oczywiście miłość i przyjaźń; to z miłości do Kaśki Jacek decyduje się, że napisze referat o kobiecych strojach. To miłość do przyszłej mamy Jaśka sprawiła, że jego tata ma na twarzy bliznę. Z miłości do ciągutek dziadek czeka na znak babci, a z miłości do dziadka wnuczek wypatruje od niego jakiejś wieści. To miłość i troska o młodsze rodzeństwo skłaniają starszego brata do trudu regularnego czytania. Miłość spaja całą rodzinę Ciumków. To dzięki temu uczuciu członkowie rodziny radzą sobie z codziennymi problemami oraz wybaczają sobie błędy. Beręsewicz przypomina, że miłość to przecież dążenie kochającego człowieka do działania na rzecz dobra drugiej osoby ${ }^{6}$.

\section{Literatura}

Ariès P., 1995, Historia dzieciństwa. Dziecko i rodzina $w$ dawnych czasach, Ochab M., przeł., Gdańsk.

Beręsewicz P., 2005, Jak zakochałem Kaśkę Kwiatek, Kraków.

Beręsewicz P., 2007, Ciumkowe historie, w tym jedna smutna, Kraków.

Beręsewicz P., 2010, Tajemnica człowieka z blizna, Łódź.

Beręsewicz P., 2018, Ściśle tajne, Łódź.

Czerwińska-Rydel A., 2017, Słońcem na papierze, Kraków.

Dymara B., Ogrodzka-Mazur E., 2013, Dziecko w świecie literatury i życiu współczesnym, Cieszyn-Bielsko-Biała-Kraków.

Jarosz E., 2017, Dziecko i dzieciństwo - pejzaż współczesny. Rzecz o badaniach nad dzieciństwem, „Pedagogika Społeczna”, nr 2 (64), s. 57-81.

Key E., 2005, Stulecie dziecka, Moszczeńska I., przeł., Warszawa.

${ }^{5}$ Co ciekawe, nawiązuje do tego biografia Kornela Makuszyńskiego dla dzieci napisana przez Annę Czerwińską-Rydel. Nosi ona tytuł Słońcem na papierze (Czerwińska-Rydel, 2017).

${ }^{6}$ Definicja „miłości”. Encyklopedia PWN. https://encyklopedia.pwn.pl/haslo/milosc;3941590. html [data dostępu: 15.10.2019]. 
Kubale A., 1984, Dziecko romantyczne. Szkice o literaturze, Wrocław.

Leszczyński G., 2006, Kulturowy obraz dziecka i dzieciństwa w literaturze drugiej połowy XIX i w XX w. Wybrane problemy, Warszawa.

Leszczyński G., 2012, Książki pierwsze, książki ostatnie. Literatura dla dzieci i młodzieży wobec wyzwań nowoczesności, Warszawa.

Zając M., 2013, Książka i młody czytelnik, Warszawa.

\section{Źródła internetowe}

Internetowy słownik języka polskiego. https://sjp.pl/trickster [data dostępu: 15.10.2019]. Encyklopedia Fantastyki. http://encyklopediafantastyki.pl/index.php/Trickster [data dostępu: 15.10.2019].

Encyklopedia PWN. https://encyklopedia.pwn.pl/haslo/milosc;3941590.html_[data dostępu: 15.10.2019].

Ewolucja poglądów na dziecko i okres dzieciństwa, w: Encyklopedia dzieciństwa. http:// encyklopediadziecinstwa.pl/index.php/Ewolucja_pogl\%C4\%85d\%C3\%B3w_na_ dziecko_i_okres_dzieci\%C5\%84stwa [data dostępu: 24.03.2020].

Oliwia Brzeźniak-Pałgan - doktor nauk humanistycznych, biblioterapeutka, członek polskiej sekcji IBBY, pracownik Miejskiej Biblioteki Publicznej im. Łukasza Górnickiego „Galeria Książki” w Oświęcimiu; redaktor działu Książki na portalu Czas Dzieci.

email: oliwiabrzezniak@onet.eu 